\title{
Relationships between Global Climate Indices and Rain-fed Crop Yields in Highland of South-Central Java, Indonesia
}

\author{
Bayu D.A. NUGROHO ${ }^{*+}$, Ardiansyah O.D. PRIMA**, Hiromitsu KANNO ***, \\ Ryoji SAIMESHIMA****, Hiroshi FUJII ${ }^{* * * * *}$ and Larry C.M. LOPEZ ${ }^{* * * * *}$
}

[Received 23 February, 2012; Accepted 18 December, 2012]

\begin{abstract}
Although there has been a high interest to investigate the relationship between climate and crop yields in Indonesia, little evidence is available for crops in highland of the country. This study evaluates the relationships between global climate indices (Southern Oscillation Index, SOI; sea surface temperature, SST) and rain-fed crop yields in Gunungkidul district, highland of South-Central Java. Principal Component Analysis (PCA) approach was used to summarize the averaged SSTs during planting season for the El Niño monitoring regions: IOBW (Indian Ocean Basin-Wide), Niño.West and Niño.3. Crops yield of each sub-district of the area was detrended using a 5-year moving average to enhance reliability of the data. For some sub-districts, the first principal component of SSTs was negatively correlated to crop yield residuals of corn and soybean while SOI was positively correlated to that of corn and dryland paddy.
\end{abstract}

Key words : crop yield, SST, SOI, rain-fed agriculture, Principal Component Analysis (PCA)

\section{Introduction}

Many studies have shown the relationship between climate indices and crops production in Indonesia (Amien et al., 1996; Kirono and Khakim, 1998; Naylor et al., 2002; Irawan, 2002). Indonesia consistently experiences dry climatic conditions and droughts during the warm phase of the El Niño-Southern Oscillation (ENSO) cycle (Naylor et al., 2001). The decrease of rainfall during the growing season, mostly lead by El Niño, critically affects the rain-fed agriculture.
El Niño events which delay the beginning of the rainy season are threatening the stability of food security (McPhaden, 1999; Hamada et al., 2002). During previous two events (1982-1983 and 1997-1998), harvest areas for paddy have decreased to approximately 670 and 700 thousand hectares, respectively. These numbers gave the total loss to the Indonesian economy for about US $\$ 2.75$ billions (BAPPENAS, 1999). Naylor et al. (2007) showed that a marked increase in the probability of a 30-day delay in monsoon onset in 2050 , as a result of changes in the mean climate.

\footnotetext{
* The United Graduate School of Agricultural Sciences, Iwate University, Morioka, 020-8550, Japan

** Faculty of Software and Information Science, Iwate Prefectural University, Iwate, 020-0193, Japan

*** NARO Tohoku Agriculture Research Center, Morioka, 020-0198, Japan

**** Faculty of Agriculture, Hokkaido University, Sapporo, 060-0810, Japan

***** Faculty of Agriculture, Yamagata University, Tsuruoka, 997-8555, Japan

+ Present address: Department of Agricultural Engineering, Faculty of Agricultural Technology, Gadjah Mada University
} 
Therefore, reliable studies on the relationship between climate indices and crops remain one of the foremost works to secure the food production in the country.

The island of Java produces rice more than $50 \%$ of the total amount of the national production (Central Bureau of Statistics, 2007), making this area the biggest contribution of rice production in Indonesia. Compared to other places, Java has an intensive agriculture and a well-developed irrigation system. Around $50 \%$ of farmlands in this area are irrigated. However, the dryland agriculture, mostly in the southern highland of the island still remains for $41 \%$. Irawan (2002) indicated that the El Niño events had dramatically decreased the crop yields for this area. An effort to cope with the threat of food insecurity for areas of highland is considered to play an important role to the food security under climate change.

In this paper, we analyze the relationship between global climate indices and rain-fed crop yields in Gunungkidul district, highland of SouthCentral Java, Indonesia and global climate indices represented by the Southern Oscillation Index (SOI) and sea surface temperature (SST). This work aims to describe which crops and parts of the study area are sensitive to the changes of global climate indices. The results may contribute to a better understanding of spatial and temporal variability of the global climate indices against small regions of the study area.

\section{Study area}

Gunungkidul district was selected as a study area (Fig. 1). Based on its topography, Gunungkidul is divided into three zones: North Zone (Patuk, Gedangsari, Nglipar, Ngawen, Semin, and northern part of Ponjong sub-district), Central Zone (Playen, Wonosari, Karangmojo, central part of Ponjong, and northern part of Semanu), and South Zone (Panggang, Tepus, Paliyan, Rongkop, southern part of Semanu, and southern part of Ponjong). These zones have elevation ranging 200-700 m, 150-200 $\mathrm{m}$ and 0-300 $\mathrm{m}$ above sealevel, respectively. Gunungkidul is characterized by its karst that is not suitable for farming due to lack of water during dry season. The average



Fig. 1 The 18 sub-districts of Gunungkidul and its topography. The variations in elevations show distinct landscape characteristics of each district.

annual rainfall is $2,500 \mathrm{~mm}$. Most of the farmers in this area practice rain-fed agricultures and cultivate multiple cropping systems. They use pranata mangsa, a worldview based on the Javanese lunar cyclical calendar, to decide their planting schedule. Major agricultural product is cassava that once established can endure drought and heat effectively. Other products include corn, soybean, upland (dryland) rice and legumes. Figure 2 shows rainfall distribution and cropping patterns in various land types in Gunungkidul (Falcon et al., 1984). Corn is planted first at the beginning of the rainy season, and the cassava that follows about a month later is left for up to 20 months before harvest. Legumes are interplanted with the cassava and corn.

\section{Data and methods}

\section{1) Crop yields}

Data of annual crop yields (dryland paddy, corn, cassava and soybean) from 1994 to 2009 were collected from twelve sub-districts of Gunungkidul: 


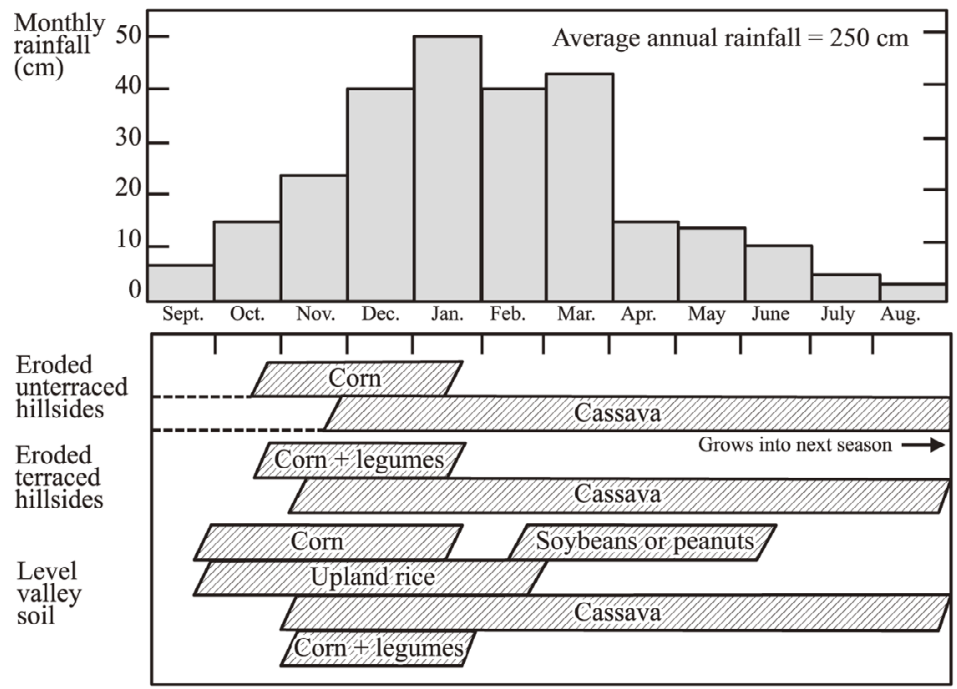

Fig. 2 Monthly rainfall distribution and cropping patterns based on three landform types (level valey soil, eroded terrace and unterraced hillsides) in Gunungkidul (Falcon et al., 1984).

Panggang, Paliyan, Tepus, Rongkop, Nglipar, Semanu, Playen, Patuk, Ngawen, Wonosari, Karangmojo, and Ponjong (Fig. 1). Data for the remaining three sub-districts: Gedangsari, Semin, and Saptosari were unable to qualify for this study. Figure 3 shows boxplots of annual crop yields for each sub-district. The yield of cassava accounted for four times greater than any other crops. Moreover, it is approximately normally distributed as indicated from the location of the medium values on the plot, showing its high level of resistance to climate constraints. On the contrary, the boxplot indicates skewed distribution for yields of paddy and soybean.

We assumed that climatic influences on crops yields generally occurred at a higher frequency than that of non-climatic. However, in order to avoid reliability issues and errors associated with the data, the observed crop yields were detrended using a low-pass spectral smoothing filter (Press et al., 1989) with a 5-year moving average. For the analysis, we calculated crop yield residuals (Martinez et al., 2009) as follows:

$$
y_{\text {residual }}=\frac{y_{\text {observed }}}{y_{\text {smoothed }}}-1
$$

While the residuals maintain the trend of each data, each data were regularized $($ mean $=0)$ to enable direct observation of statistical fluctuation of the crop yields for each sub-district.

\section{2) Global climate indices}

SOI and SSTs from 1994 to 2009 were used to represent global climate indices for this study. Monthly averaged SOI from 1994 to 2009 was acquired from the Australian Bureau of Meteorology (BOM). The method used by the BOM to calculate the SOI is the Troup SOI, which is the standardized anomaly of the mean sea level pressure difference between Tahiti and Darwin. Monthly averaged SSTs of the El Niño monitoring region (Fig. 4) : Niño. $3\left(5^{\circ} \mathrm{N}-5^{\circ} \mathrm{S}, 150-90^{\circ} \mathrm{W}\right)$, Niño.West $\left(0^{\circ}-15^{\circ} \mathrm{N}, 130-150^{\circ} \mathrm{E}\right)$, and the Indian Ocean Basin-Wide (IOBW), $\left(20^{\circ} \mathrm{S}-20^{\circ} \mathrm{N}, 40-100^{\circ}\right.$ $\mathrm{E})$ were acquired from the Japan Meteorological Agency (2012).

For the analysis, at first, we recalculated the values of SOI and SSTs by averaging their 6-month values for each rainy season (OctoberMarch). Here, October is the onset of the rainy and the beginning of the planting season in Gunungkidul (Sardjiman and Mulyadi, 2005). The SSTs from Niño.3, Niño.West, and IOBW were integrated using Principal Component Analysis (PCA) to enable direct comparisons between SST 

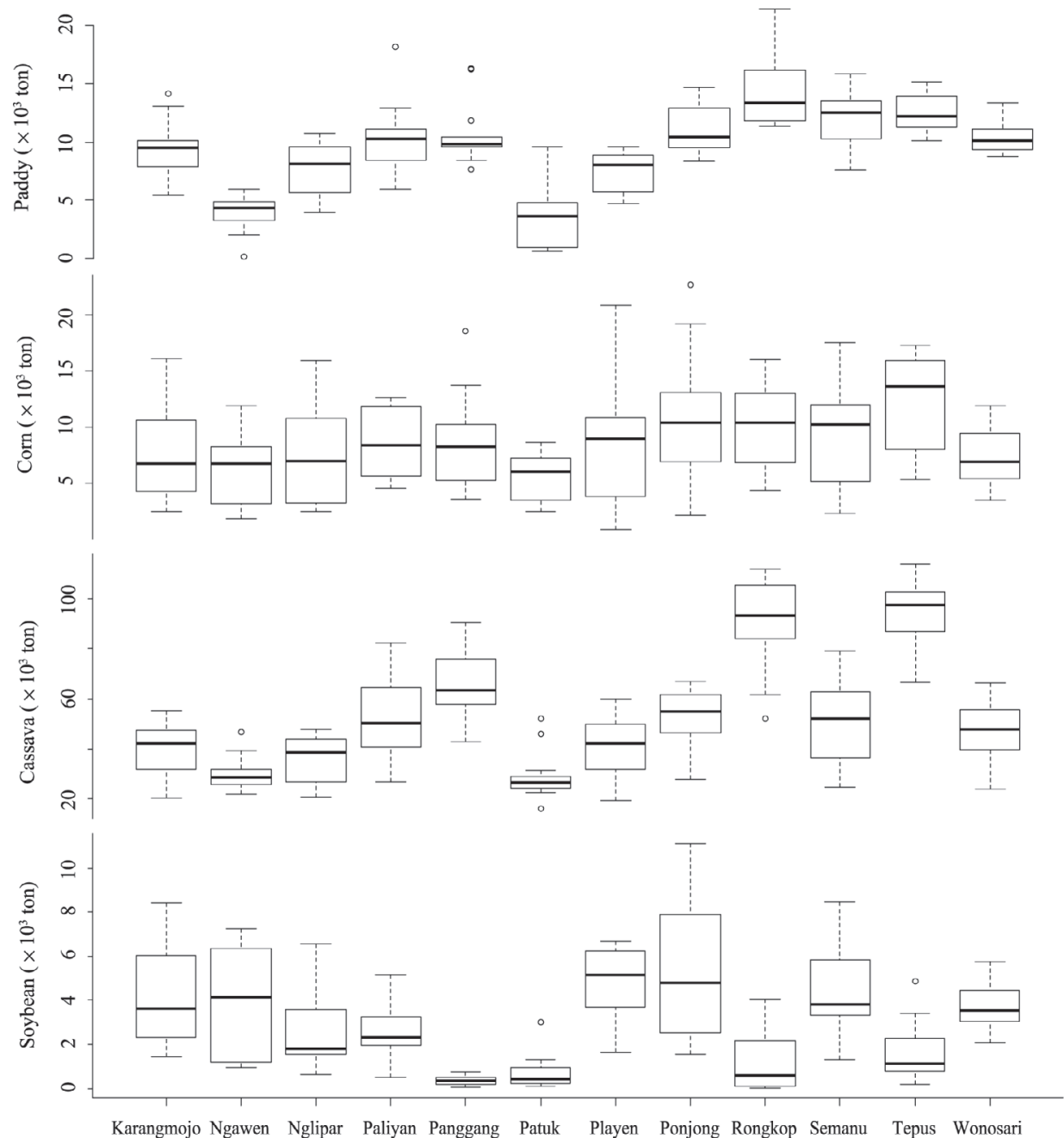

Fig. 3 Boxplots showing the statistical distributions of annual crop yields (paddy, corn, cassava, and soybean) for each subdistrict from 1994 to 2009 . The lower and upper bars show minimum and maximum, respectively. The bottom and top of the box are lower and upper quartiles while the band near the middle of the box shows the medium value of the data. Circles show outliers of the data.

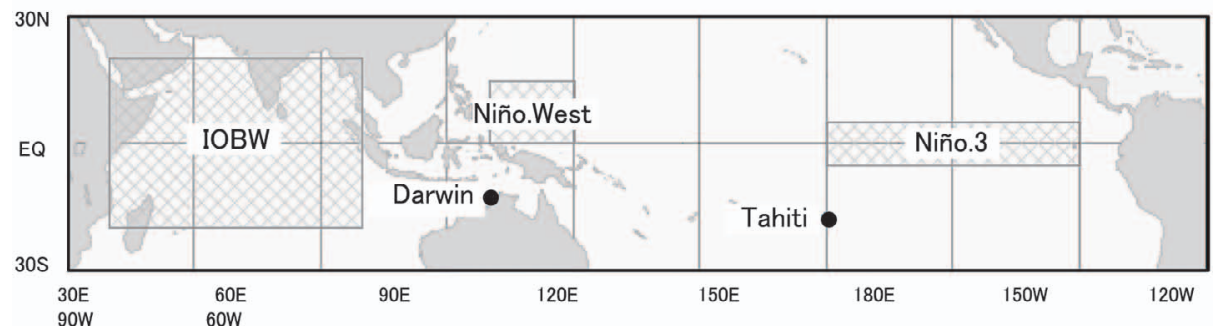

Fig. 4 The three El Niño monitoring region (shaded regions) to observe the relationship among SSTs in the eastern (Niño.3), the western Pacific (Niño.West), and Indian Ocean (IOBW). 
and each crop yield residual. For this study, only principal components (PCs) having at least 70\% of cumulative proportion of variances were used in correlation analysis with other data. Finally, we performed linear correlation analyses to identify significant relationships between the crop yield residual of each sub-district with the associated SOI and PCs. Using the resulted significant indices, linear regression analyses were performed to evaluate the potential predictability of yield residuals with those combinations of the indices.

\section{3) Local rainfall data}

Although the main purpose of this study is to analyze the relationship between global climate indices and rain-fed crop yields, we collected monthly cumulative rainfall data during the rainy season (October-March) from 1994 to 2009 for each sub-district to locally interpret the analysis results of this study. Figure 5 shows the distribution of averaged annual precipitation during the rainy season. The precipitation was relatively low for Karangmojo, Paliyan, Ponjong, Semanu, and Wonosari. These areas correspond to the basin as shown in Fig. 1. Here, we considered that the topography essentially affects the rainfall distribution in Gunungkidul.

\section{Results}

\section{1) Principal Components for the SSTs}

Table 1 shows PC loadings and its statistical variances. The first PC (PC1) of IOBW and Niño. 3 shows positive loadings meaning that the SSTs from those two regions were in phase. The contrast between Niño.3 and Niño.West shows that the PC1 strongly links with El Niño and/ or La Niña events. For this study, only PC1 was used to represent the SSTs for the three regions as its cumulative proportion exceeded $70 \%$ of the total variance (value in bold). Figure 6 shows the original global climate indices and the resulted PC1 from the SSTs. The El Niño in 1998 was distinctly indicated in this figure.

2) Association of global climate indices and crop yield residuals

Correlation of global climate indices with crop yield residuals is shown in Table 2. SOI was

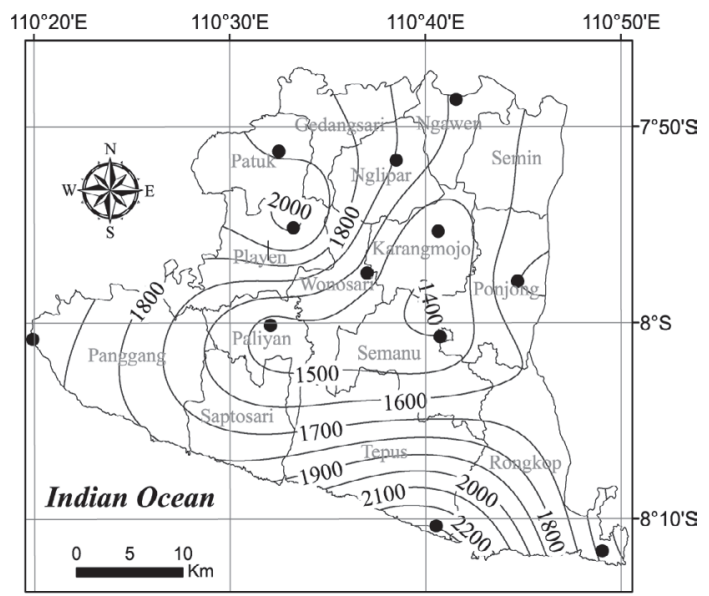

Fig. 5 Distribution of averaged annual precipitation during the rainy season based on 1994-2009 rainfalls in Gunungkidul district (dot show rain gauges used in this study). High rainfalls were observed for districts in western and southern parts of the area.

Table 1 Principal component loadings and their importance of components for each PC against the SSTs (Niño.3, Niño.West, and IOBW).

\begin{tabular}{lrrr}
\hline & PC1 & PC2 & PC3 \\
\hline Regions of SST & & & \\
$\quad$ IOBW & 0.533 & 0.699 & -0.476 \\
Niño.West & -0.527 & 0.715 & 0.460 \\
$\quad$ Niño.3 & 0.662 & 0.005 & 0.749 \\
Importance of components & & & \\
$\quad$ Stdev & 1.485 & 0.859 & 0.243 \\
$\quad$ Proportion of variance & 0.735 & 0.246 & 0.020 \\
$\quad$ Cumulative proportion & $\mathbf{0 . 7 3 5}$ & 0.980 & 1.000 \\
\hline
\end{tabular}





Fig. 6 The original global climate indices (top) and the resulted PC1 of SSTs (bottom). Niño.3 shows the most similar trend with PC1 as indicated by its high loadings in PC1.

Table 2 Pearson's correlation between the global climate indices (SOI and PC1) and crop yield residuals (dry paddy, corn, cassava, and soybean) for each district of the study area.

\begin{tabular}{|c|c|c|c|c|c|c|c|c|c|c|c|c|}
\hline & Panggang & Paliyan & Tepus & Rongkop & Nglipar & Semanu & Playen & Patuk & Ngawen & Wonosari & Karang Mojo & Ponjong \\
\hline \multicolumn{13}{|c|}{ SOI vs crop residuals } \\
\hline Dry & $0.512^{*}$ & 0.223 & -0.126 & 0.093 & 0.364 & -0.078 & 0.406 & $0.528^{*}$ & 0.154 & 0.211 & 0.186 & 0.267 \\
\hline Corn & 0.444 & 0.125 & 0.217 & 0.322 & -0.130 & 0.305 & -0.181 & 0.365 & -0.203 & $0.500^{*}$ & -0.015 & 0.298 \\
\hline Cassava & -0.149 & 0.293 & -0.227 & 0.205 & -0.230 & -0.228 & -0.334 & 0.083 & -0.137 & -0.192 & 0.086 & -0.117 \\
\hline Soybean & 0.387 & 0.328 & 0.345 & 0.494 & -0.057 & 0.487 & 0.417 & 0.432 & 0.227 & 0.231 & 0.310 & 0.197 \\
\hline \multicolumn{13}{|c|}{ PC1 vs crop residuals } \\
\hline Dry & -0.434 & -0.262 & 0.311 & -0.163 & -0.321 & 0.121 & -0.411 & -0.422 & 0.009 & -0.153 & -0.111 & -0.277 \\
\hline Corn & -0.368 & -0.196 & -0.192 & -0.293 & 0.030 & -0.390 & 0.203 & -0.339 & 0.023 & $-0.519^{*}$ & 0.058 & -0.223 \\
\hline Cassava & 0.416 & -0.306 & 0.307 & -0.030 & 0.282 & 0.339 & 0.458 & -0.019 & 0.110 & 0.266 & -0.011 & 0.225 \\
\hline Soybean & -0.311 & -0.396 & -0.358 & $-0.510^{*}$ & 0.072 & $-0.607^{*}$ & -0.313 & $-0.513^{*}$ & -0.223 & -0.424 & -0.363 & -0.408 \\
\hline
\end{tabular}

* Significant at $p<0.05$.

negatively correlated with crop yield residuals of dryland paddy in Patuk and Panggang, and of corn in Wonosari. The relationships between these residuals and SOI were found as

$$
y_{\mathrm{p}}(i)=0.0131^{*} \mathrm{SOI}(i)+0.0171
$$

for dryland paddy $\left(y_{\mathrm{p}}\right)$, and as

$$
y_{\mathrm{c}}(i)=0.0138 * \mathrm{SOI}(i)+0.0204
$$

for corn $\left(y_{\mathrm{c}}\right)$ where $i$ represents the observation year. On the other hand, PC1 shows negative correlation with crop yield residuals of corn in Wonosari and of soybean in Rongkop, Semanu, and Patuk. The relationships between these residuals and $\mathrm{PC} 1$ were found as

$$
y_{\mathrm{c}}(i)=-0.1472 * \operatorname{PC} 1(i)+2.4429
$$

for corn $\left(y_{\mathrm{c}}\right)$, and as

$$
y_{\mathrm{s}}(i)=-0.2543^{*} \mathrm{PC} 1(i)+4.1834
$$

for soybean $\left(y_{\mathrm{s}}\right)$, respectively.

Figure 7 shows these crop yield residuals (solid lines) and their predicted values (dashed lines) for the sub-districts mentioned above. Overall, the predicted values resulted from the regression analyses show a good resemblance to 


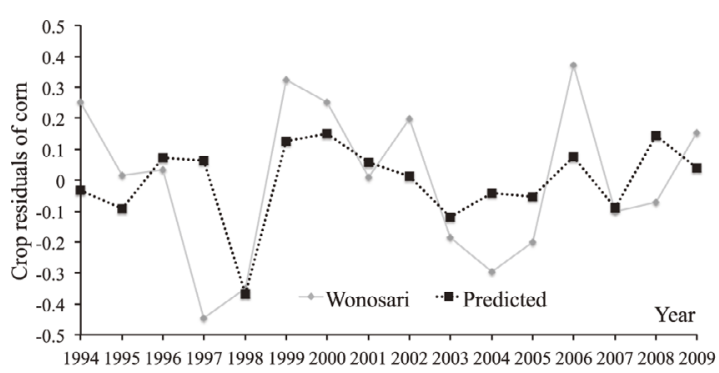

(a)

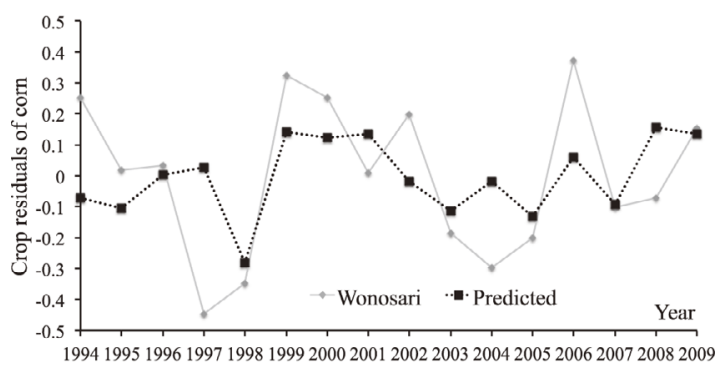

(c)

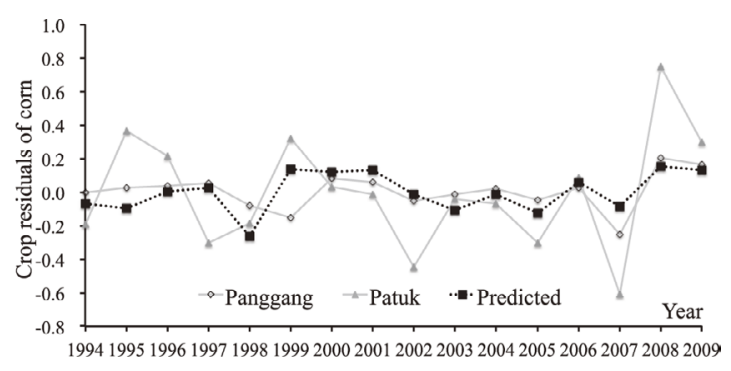

(b)

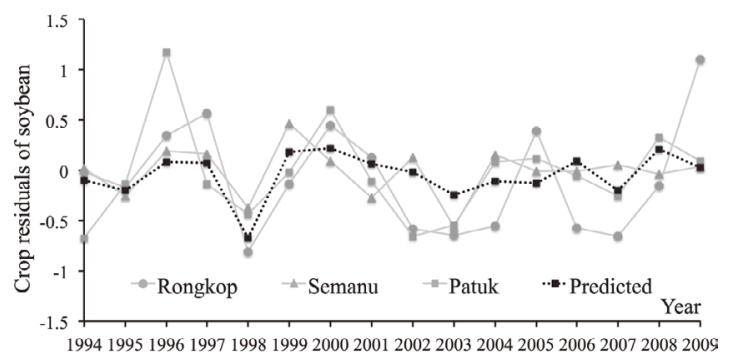

(d)

Fig. 7 Crop yield residuals and their predicted values for some sub-districts having significant correlations with the global climate indices as shown in Table 2.

(a) Crop yield residuals of corn and its predicted values from SOI. (b) Crop yield residuals of paddy and its predicted values from SOI. (c) Crop yield residuals of corn and its predicted values from PC1. (d) Crop yield residuals of soybean and its predicted values from PC1.

the residuals. This observation indicates that the global climate indices were associated with corn, soybean, and paddy to some sub-districts.

To assess the advantage of using global climate indices in crop yield prediction, we correlated directly the amount of crop yields with the averaged rainfall data of October to December (OND) for those sub-districts (Fig. 8). Here, crop yields and rainfall data were previously smoothed using 5-year moving average to show their long trends. Strong correlations were found at Patuk and Wonosari (Figs. 8a, e, f) but not at Panggang, Rongkop, and Semanu (Figs. 8b, c, d). The former are areas of the North and the Central Zones with relatively distant from the sea while the latter are areas of the South Zone. Based on this observation, the global climate indices used in this study show better representation to the crop yields than the locally measured rainfall. Significant relationships were not found in successive analyses with the annual rainfall data for January to March (JFM) and will not be addressed further in this paper.

\section{Discussion}

In this study, we have revealed significant relationships among rain-fed crop yield residual in highland and global climate indices. While some study has reported that the variability of temperature, rainfall, and extreme events are forecast to have profound effects on crop yields for arid areas including highlands (Adams et al., 1998; Burton, 2001), these climate indices are difficult to be predicted at inter-annual time scales. Our results open the possibility to predict crop yields in long term to some extent because methods to predict seasonal SOI and SST have been well developed. Future SOI can be effectively predicted using a polynomial function applied to the time series of the past SOI with the aid of Hilbert transform and empirical mode decomposition (EMD) procedure (Salisbury and Wimbush, 2002). On the other hand, SSTs can be predicted using JMA's (Japan 


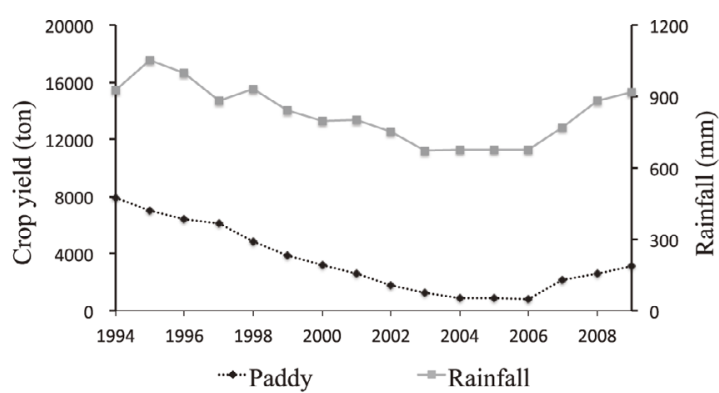

(a)

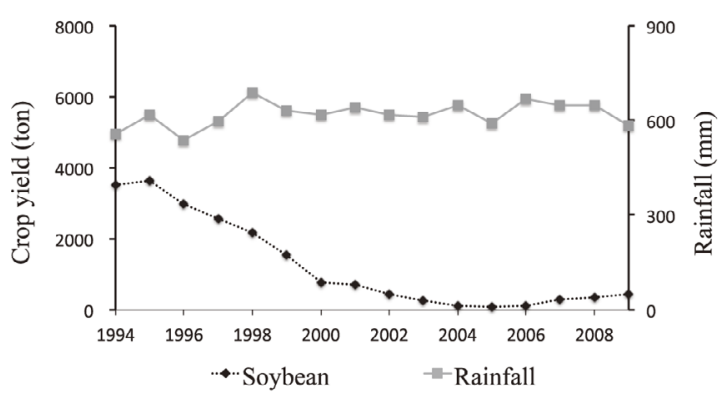

(c)

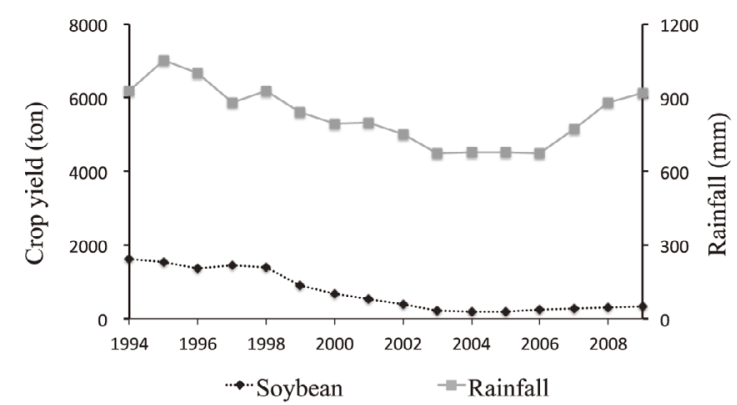

(e)

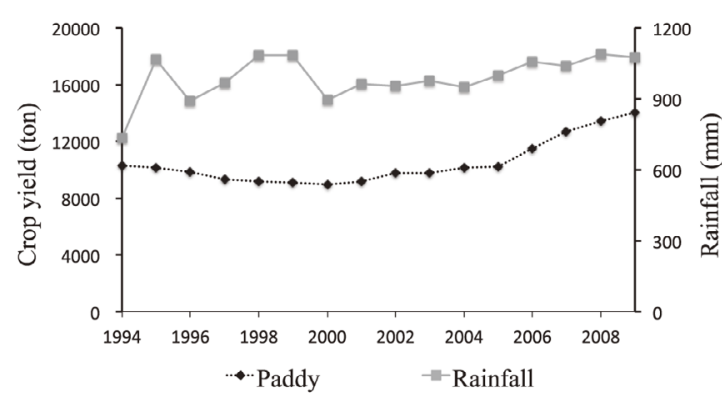

(b)

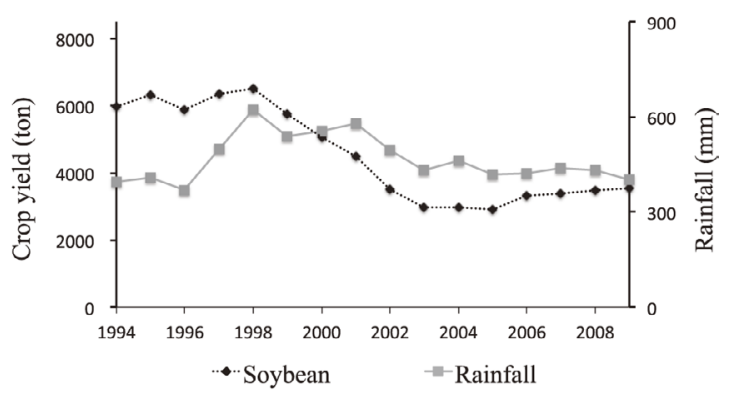

(d)

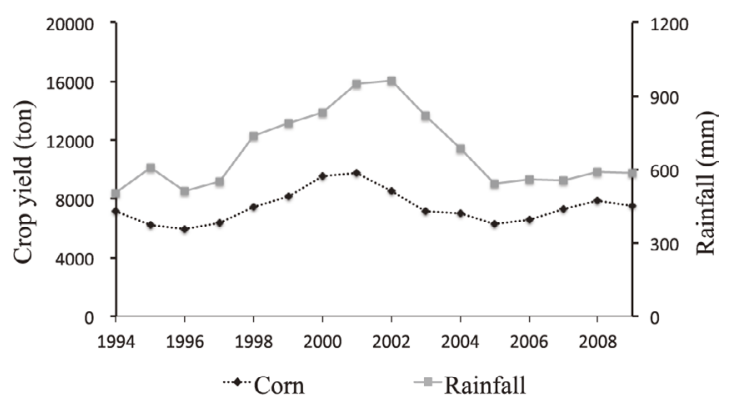

(f)

Fig. 8 Variability of crop yields and annual rainfall (OND) from 1994 to 2009 (** Significant at $p<0.01$ ).

(a) Paddy and rainfall for Patuk $\left(r=0.88^{* *}\right)$. (b) Paddy and rainfall for Panggang $(r=0.38$ ). (c) Soybean and rainfall for Rongkop $(r=-0.42)$. (d) Soybean and rainfall for Semanu $(r=0.29)$. (e) Soybean and rainfall for Patuk $\left(r=0.80^{* *}\right)$. (f) Corn and rainfall for Wonosari $\left(r=0.78^{* *}\right)$.

Meteorological Agency) El Niño prediction model (Ishikawa et al., 2005), a coupled atmosphereocean model that consists of an atmospheric general circulation model (AGCM) and an ocean general circulation model (OGCM).

The results of this study may be used to select suitable crops in multiple cropping systems with higher resistance to the extreme changes of the global indices. Our methods to analysis the relationships between global climate indices and rain-fed crop yields in highland may apply to areas with similar topography and climate field in Indonesia and to other area over the semiarid zone. Forecasting global climate indices will become important materials for the improvement of agriculture in the semi-arid areas by using our proposed methods.

Finally, the achievement in this study provides valuable information to the policymaker in agriculture for this area, not only to estimate crop 
yield but also to decide the starting date of planting season and suitable plants for the multiple cropping systems. Although as already stated above, climatic factors contributed to the multiple crop system in this area, further analyses will be conducted to reveal non-climatic factor to enhance and to get more robust and applicable results.

\section{Conclusion}

In this study, we have investigated the relationship between global climate indices and crop yields in highland of South-Central Java, Indonesia. The analyses were effectively conducted by summarizing the SSTs using PCA and by calculating the residuals of crop yields for each sub-district of the study area. For some districts, the first principal component of the SSTs was negatively correlated to crop yield residuals of corn and soybean while SOI was positively correlated to that of corn and dryland paddy. Using these relationships, linear regressions were successfully constructed to predict the crop yields. Our techniques can be useful and enhanced for predicting crops in highland.

\section{Acknowledgement}

The authors thank two anonymous reviewers for their helpful comments and advices.

\section{References}

Adams, R.M., McCarl, B.A. and others (1998): Climate Change and U.S. Agriculture: Some Further Evidence. Report prepared for the Electric Power Research Institute as part of the Agricultural Impacts Project of the Climate Change Impacts Program (CCIP).

Amien, I., Rejekiningrum, P., Pramudia, A. and Susanti, E. (1996): Effects of interannual climate variability and climate change on rice yield in Java, Indonesia. Water Air and Soil Pollution, 92, 29-39.

BAPPENAS (1999): Planning for Fire Prevention and Drought Management Project. Final Report of TA2999-INO. Asian Development Bank and BAPPENAS (Indonesian National Development Planning Agency), Jakarta, Indonesia.

Burton, I. (2001): Vulnerability and Adaptation to Climate Change in the Drylands. The Global Drylands Partnership, Washington, D.C.

Central Bureau of Statistics (2007): Republic of Indonesia, Key indicators of Indonesia. Booklet Indicator Kunci. BPS-Indonesia.

Falcon, W.P., Jones, W.O. and Pearson, S.R. eds. (1984): The Cassava Economy of Java. Stanford University
Press, Standford California, 28-32.

Hamada, J.I., Yamanaka, M.D., Matsumoto, J., Fukao, S., Shibano, Y., Winarso, P.A. and Sribimawati, T. (2002): Spatial and temporal variations of the rainy season over Indonesia and their link to ENSO. Journal of the Meteorological Society of Japan, 80, 285-310.

Irawan, B. (2002): Stabilization of upland agriculture under El Nino-induced climatic risk: Impact Assessment and Mitigation Measure in Indonesia, Economics and Social Commission for Asia and the Pacific. CGPRT Center WORKING PAPER, 62, 1-51.

Ishikawa, I., Tsujino, H., Hirabara, M., Nakano, H., Yasuda, T. and Ishizaki, H. (2005): Meteorological Research Institute Community Ocean Model (MRI. COM) manual. Technical Reports of the Meteorological Research Institute, 47, 189.

Japan Meteorological Agency (2012): Retrieved 27 November 2012.

http://ds.data.jma.go.jp/tcc/tcc/products/elnino/ elmonout.html [Cited 2012/11/27].

Kirono, D.G.C. and Khakim, N. (1998): Rainfall and El Nino Southern Oscillation: Link and its impact on crop production, a case study of Yogyakarta Special Province of Indonesia. The Indonesian Journal of Geography, 30, 21-34.

Martinez, C.J., Baigorria, G.A. and Jones, J.W. (2009): Use of climate indices to predict corn yields in southeast USA. International Journal of Climatology, 29, 1680-1691.

McPhaden, M.J. (1999): Genesis and evolution of the 1997-1998 El Nino. Science, 283, 948-949.

Naylor, R.L., Falcon, W.P., Rochberg, D. and Wada, N. (2001): Using El Nino/Southern Oscillation climate data to predict rice production in Indonesia. Climatic Change, 50, 255-265.

Naylor, R.L., Falcon, W.P., Wada, N. and Rochberg, D. (2002): Using El Nino-Southern Oscillation climate data to improve food policy planning in Indonesia. Bulletin of Indonesian Economic Studies, 38, 75-91.

Naylor, R.L., Battisti, D.S., Vimont, D.J., Falcon, W.P. and Burke, M.B. (2007): Assessing risks of climate variability and climate change for Indonesian rice agriculture. Proceedings of the National Academy of the United States of America (PNAS), 104, 7752-7757.

Press, W.H., Flannery, B.P., Teukolsky, S.A. and Vetterling, W.T. (1989): Numerical Recipes: The Art of Scientific Computing. Cambridge University Press, New York, NY, USA, 702.

Salisbury, J.I. and Wimbush, M. (2002): Using modern time series analysis techniques to predict ENSO events from the SOI time series. Nonlinear Processes in Geophysics, 9, 341-345.

Sardjiman and Mulyadi (2005): Analisis neraca air lahan kering pada iklim kering untuk mendukung pola tanam. Balai Pengkajian Teknologi Pertanian, DI Yogyakarta, 1-6. (in Indonesian) 


\title{
インドネシアジャワ島南央部における高地の天水農業の収量と グローバル指数との関係について
}

\author{
バユドウィアプリヌグロホ*+ プリマオキデイッキアルディアンシャー** \\ 菅野洋 光*** 鮫 島良次**** 藤井弘志***** \\ ラリーロペス*****
}

インドネシアにおいては気候と農作物収量との 関係に高い関心が寄せられているが，高地農業に 関しては進展が少ない状況である。本研究では, 南方振動指数 (SOI) および海水面温度 (SST) のグローバル指数とジャワ島南央部に位置する グヌンキドゥール地区における天水農作物収量と の関係を分析した。3つの地域 (IOBW, Niño. West およびNiño.3）のSSTに対して主成分分
析（PCA）を適用し，その代表となる主成分を 抽出した。各地域の作物収量デー夕の信頼性を向 上させるために，元の収量データとその 5 年移 動平均值から残差を計算し，正規化した。いくつ かの地域では，SSTの第 1 主成分とトウモロコ シ・ダイズの残差との間に負の相関を示し，また SOI はトウモロコシ・陸稲の残差との間に正の 相関を示すことが明らかとなった。

キーワード : 農作物収量, 海水面温度, 南方振動指数, 天水農業, 主成分分析

\footnotetext{
* 岩手大学大学院連合農学研究科

** 岩手県立大学ソフトウェア情報学部

*** (独) 農研機構東北農業研究センター

***** 北海道大学農学部

***** 山形大学農学部

+ 現所属 : Department of Agricultural Engineering, Faculty of Agricultural Technology, Gadjah Mada University
} 